\title{
Up-to-date in ovarian cancer
}

Cancer of the ovary account for most deaths resulting from cancer of the female genital tract. This relates primarily to the fact that, unlike other common malignant gynecologic neoplasms (cancer of the endometrium and cervix), cancers of the ovary are first seen at relatively advanced stages of disease because of the lack of an effective screening or diagnostic test. According to GLOBOCAN 2018, malignant ovarian tumors represents the $18^{\text {th }}$ malignant neoplasm in the World when we considered both male and female population, but occupies the $8^{\text {th }}$ place in women, with almost 300 thousand cases around the globe. Regarding mortality, represent the $14^{\text {th }}$ cause of death by cancer in the World when considering both sexes, but the $8^{\text {th }}$ place in women, with more than 180 thousand deaths by ovarian cancer in 2018. In China and Mexico, the incidence rates are 5.4 and $6.8 \times 100,000$ women, respectively.

In the recent years, great advances in the knowledge and treatment of ovarian cancer has been made. In the present series of Chinese Clinical Oncology, a complete review of the recent advances in diagnosis and treatment of ovarian neoplasms has been performed. A group of Mexican experts in gynecologic oncology describe the epidemiology and diagnostic advances in ovarian cancer. Other reviews emphasize recent controversies in the management of ovarian neoplasms, like the optimal surgery in no-epithelial ovarian carcinoma, the role of hyperthermic intraperitoneal chemotherapy (HIPEC) or fertilitysparing treatment in ovarian cancer and how far should we go in optimal cytoreductive surgery, the use of PARP inhibitors, dose-dense chemotherapy or radiation therapy in this group of neoplasms.

We hope that the extensive review of recent literature be helpful for all the medical specialties involved in the multidisciplinary care of ovarian cancer patients in order we can reduce the fatality rate of this dreadful disease.

\section{Acknowledgments}

Funding: None.

\section{Footnote}

Provenance and Peer Review: This article was commissioned by the editorial office, Chinese Clinical Oncology, for the series "Ovarian Cancer". The article did not undergo external peer review.

Conflicts of Interest: The author has completed the ICMJE uniform disclosure form (available at http://dx.doi.org/10.21037/ cco-2019-oc-13). The series "Ovarian Cancer" was commissioned by the editorial office without any funding or sponsorship. Dr. HMF served as the unpaid Guest Editor of the series, and serves as an unpaid editorial board member of Chinese Clinical Oncology from Jan 2019 to Dec 2020.

Ethical Statement: The author is accountable for all aspects of the work in ensuring that questions related to the accuracy or integrity of any part of the work are appropriately investigated and resolved.

Open Access Statement: This is an Open Access article distributed in accordance with the Creative Commons AttributionNonCommercial-NoDerivs 4.0 International License (CC BY-NC-ND 4.0), which permits the non-commercial replication and distribution of the article with the strict proviso that no changes or edits are made and the original work is properly cited (including links to both the formal publication through the relevant DOI and the license). See: https://creativecommons.org/ licenses/by-nc-nd/4.0/. 


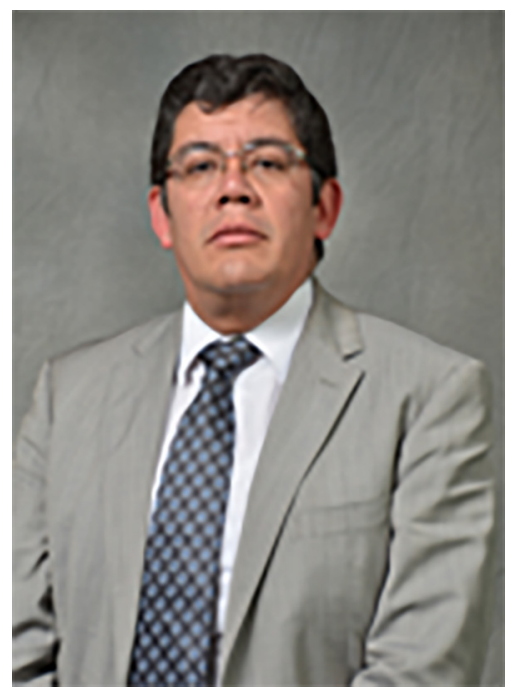

Heriberto Medina-Franco

Heriberto Medina-Franco, MD, FACS

Department of Surgery, Section of Surgical Oncology, National Institute of Medical Sciences and Nutrition "Salvador Zubirán", Mexico City, Mexico. (Email: herimd@hotmail.com) Submitted Jul 14, 2020. Accepted for publication Jul 29, 2020. doi: $10.21037 / \mathrm{cco}-2019-$ oc-13

View this article at: http://dx.doi.org/10.21037/cco-2019-oc-13

Cite this article as: Medina-Franco H. Up-to-date in ovarian cancer. Chin Clin Oncol 2020;9(4):43. doi: 10.21037/ cco-2019-oc-13 